\title{
Selection of the most proper drilling and blasting pattern by using MADM methods (A case study: Sangan Iron Ore Mine, Iran)
}

Rudarsko-geološko-naftni zbornik

(The Mining-Geology-Petroleum Engineering Bulletin) UDC: 622.2

DOI: 10.17794/rgn.2020.3.10

Preliminary communication

\author{
Ahmad Aryafar'; Mohammad Javad Rahimdel ${ }^{1}$; Ehsan Tavakkoli ${ }^{1}$ \\ ${ }^{1}$ Department of Mining Engineering, Faculty of Engineering, University of Birjand, Birjand 9717434765, Iran
}

\begin{abstract}
Drilling is the first stage of open pit mining that has a considerable effect on the other stages of mining, including blasting, loading, hauling and crushing. An unsuitable drilling pattern may lead to undesirable results such as poor fragmentation, back break and fly rock that not only results in technical and safety issues but also increases the operating cost of the mine. Multi-Attribute Decision-Making (MADM) methods can be useful approaches to select the appropriate drilling pattern among various alternatives, performed previously. This paper aims to select the most proper drilling and blasting pattern for Sangan Iron Mine, Iran. To achieve this, in the first step, rock fragmentation, back break, fly rock, specific charge and specific drilling were considered as the decision criteria and their degree of importance was calculated using the AHP method under a fuzzy environment. Then, TOPSIS and PROMETHEE methods were used to select the most proper alternative. The results of this study show that the drilling pattern with a spacing of $5 \mathrm{~m}$, burden $4 \mathrm{~m}$, hole depth $10 \mathrm{~m}$, and hole diameter $15 \mathrm{~cm}$ is the most suitable one. The stemming length and powder factor of the suggested pattern are $2.3 \mathrm{~m}$ and $2.6 \mathrm{gr} / \mathrm{cm} 3$, respectively.
\end{abstract}

Keywords:

Drilling and blasting pattern; Sangan Iron Ore Mine; AHP; TOPSIS; PROMETHEE

\section{Introduction}

Drilling and blasting play a vital role in mining projects. The quality of the blasting operation and subsequently, the adequate rock fragmentation are effective parameters that have a considerable effect on the mine productivity (Shi et al. 2012). Reduction of the mineral size to suitable fragmentation is necessary for either hauling or crushing processes. Poor fragmentation increases the operating cost of a mine and also the amount of dust in the mine atmosphere. The main aim of drilling and blasting pattern (DBP) selection is to reduce the costs of rock crushing and then improve the operational effectiveness. Nowadays, many researchers have been trying to propose the most suitable DBP. In some studies, back break was considered as a destructive phenomenon (Gate et al. 2005; Khandelwal and Monjezi 2012; Monjezi et al. 2012a, Ghasemi et al. 2016). Some studies focused on the fly rock and tried to reduce this parameter (Bajpayee et al. 2003; Bajpayee et al. 2004; Gate et al. 2005; Little and Blair 2010; Stojadinovi et al. 2011; Monjezi et al. 2007, 2012). Moreover, there have been some attempts to reduce ground vibration (Guosheng et al. 2011; Hudaverdi 2012; Bakhshandeh Amnieh et al. 2012). Regarding the past stud-

Corresponding author: Mohammad Javad Rahimdel rahimdel@birjand.ac.ir ies, effective factors in selecting the most appropriate DBP can be categorized into technical (fragmentation and back break), economical (specific charge and drilling) and safety parameters (such as fly rock, ground and air vibrations). Drilling patterns suggested by the experimental methods are not accurate enough and cannot consider all the effective criteria, mentioned earlier, simultaneously. These parameters are varied from one site to another and their degree of importance is also not the same in all cases. In such conditions, using multi-criteria decision-making (MCDM) methods to select the most proper pattern among all the options seems essential. Monjezi et al. (2012b) used the Technique for Order of Preference by Similarity to Ideal Solution, the TOPSIS method for the selection of the most appropriate DBP in the limestone Tajareh mine in Iran. In this study, drilling and blasting cost, fragmentation and fly rock were considered as decision criteria and the most proper DBP was selected among 19 patterns, performed previously. In other studies, the most suitable DBP was proposed for the Sungun Copper Mine in Azerbaijan Sharghi Province, Iran using MADM methods among 27 performed patterns (Yari et al. 2013, 2014a, 2014b, 2015, 2017). In these studies, specific drilling, powder factor, fly rock, back break and fragmentation were considered as attributes. Regarding the results of these studies, the TOPSIS method showed that the drilling pattern with a diameter of $12.7 \mathrm{~cm}$, burden of $3 \mathrm{~m}$, spacing of $4 \mathrm{~m}$ and hole 
length of $11.8 \mathrm{~m}$ was the most proper one (Yari et al. 2013). Based on the Taxonomy method, the selected pattern with a hole diameter of $15.24 \mathrm{~cm}$, burden of $3 \mathrm{~m}$, spacing of $4 \mathrm{~m}$ and stemming rate of $3.2 \mathrm{~m}$ was selected as the most suitable drilling pattern (Yari et al. 2014a, 2015) that was consistent with the ELECTRE method results (Yari et al. 2013). At the same time, the application of the liner assignment method showed that the pattern with a burden of $3.5 \mathrm{~m}$, spacing of $4.5 \mathrm{~m}$, stemming of $3.8 \mathrm{~m}$ and hole length of $12.1 \mathrm{~m}$ was selected as the most suitable pattern (Yari et al. 2015, 2017). These results indicate that, a single MADM method is not efficient to enable a complete and correct analysis and therefore to obtain a more reliable result, two or more methods should be used by utilizing the strengths of each one.

A review of past studies, mentioned above, shows that the conventional MCDM methods were used to select the most appropriate DBP is some cases. However, in most cases, it is difficult for experts and decision-makers to compute verbal and linguistic variables. In such circumstances, the uncertainties should be interpreted in a fuzzy environment. This paper aims to select the most appropriate DBP for the Sangan Iron Ore Mine in Razavi Khorasan Province, Iran among different proposed drilling patterns, performed previously. To achieve this, fragmentation, fly rock, specific drilling, back break, and specific charge have been selected as the decision criteria. To avoid ambiguities and uncertainties in obtaining the importance weight of each criterion, calculations should be done under a fuzzy environment instead of crisp values. Therefore, the degree of importance of each criterion is determined using the Analytical Hierarchy Process (AHP) method under a fuzzy environment. To select the most proper DBP, the technique for the order of preference by similarity to an ideal solution (TOPSIS) and the preference ranking organization method for enrichment evaluation (PROMETHEE) methods are used. TOPSIS is an understandable and straightforward method that is applicable to handle both qualitative and quantitative data sets. PROMETHEE is one of the new and simple MCDM methods that can derive the partial and full ranking of alternatives. This method includes both qualitative and quantitative criteria and supports grouplevel decision-making to identify the positive and negative aspects of the alternatives. PROMETHEE is a clear and stable MADM and there is no need for preferences to be expressed as linear relationships. Characterized by different types of preference functions, being a userfriendly method, and the successful application in reallife planning problems are the main advantages of this method. Nowadays, PROMETHEE has been applied in many applications in the field of mining engineering such as mining method selection (Bogdanovic et al. 2012, Kant et al. 2016, Balusa and Singam 2018, Iphar and Alpay 2019), prioritization of the mineral resources (Rahimdel and Noferesti 2020), mining equip- ment selection (Sousa Junior et al. 2014, Wang and Tu 2015), mechanization of coal mining (Ghadernejad et al. 2019) and post-mining land-use selection (Amirshenava and Osanloo 2017). TOPSIS is an understandable and straightforward method that deals with either qualitative or quantitative criteria. In the application of TOPSIS, determination of the best alternative is possible with simple calculations. TOPSIS is extremely flexible and therefore, it is possible to accommodate a further extension to make a better choice in different situations. TOPSIS has also been used in numerous mining applications such as equipment selection (Adebimpe et al. 2013, Yazdani-Chamzini 2014, Yavuz 2016), mining method selection (Gligoric and Gligoric 2015, Ooriad et al. 2018, Iphar and Alpay 2019), mining site selection (Hekmat et al. 2008, Golestanifar and Aghajani Bazzazi 2010), mine reclamation planning (Alavi 2014), and choice problems in mineral processing (Kostovic and Gligoric 2015). Although, the TOPSIS and PROMETHEE methods have been used in various fields of mining engineering, the application of these methods to select the most suitable DBP has not yet been reported. This paper aims to integrate the fuzzy-AHP-TOPSIS and also the fuzzy-AHP-PROMETHEE methods for the selection of the most proper drilling pattern for the Sangan Iron Ore mine in Razavi Khorasan Province, Iran.

This paper is divided into four sections. In section 2, the Fuzzy AHP, TOPSIS and PROMETHEE methods are represented. In section 3, the case study and the geometrical specifics of all the performed DBP are presented. Finally, in section 4, first the weight of each criterion is obtained by using the fuzzy AHP method and then the TOPSIS and PROMETHEE methods are applied to find the most proper DBP.

\section{Theoretical foundation; MCDM methods}

Multi-criteria decision-making (MCDM) is one of the branches of operation research used to prioritize and select the best available alternative considering various criteria which are sometimes opposite indices. Multiobjective decision-making (MODM) and multi-attribute decision-making (MADM) are two kinds of MCDM (Pohekar and Ramachandran 2004). MODM methods are generally used to design and optimize problems while the MADM methods are applied to select the most proper alternative among different options. Nowadays, different methods have been presented for MADM problems. This section is devoted to representing the steps of the fuzzy AHP, TOPSIS, and PROMETHEE, as the most applied MADM methods in selection problems.

\subsection{AHP under fuzzy environment}

AHP is one of the most powerful and simplest methods used to define a criteria's degree of importance in 
MADM problems. Nowadays, many successful applications of AHP have been reported in vague decision-making problems such as the selection of opencast mining equipment (Samanta et al. 2002), underground mining method selection (Gupta and Kumar 2012), the selection of a primary crusher (Rahimdel and Ataei 2014), the selection of a transportation system (Despodov et al. 2011), plant species selection for mine reclamation (Alavi 2014) and groundwater potential zones in coal mining (Kumar and Krishna, 2018). In the first step of AHP, the hierarchy structure of the problem is constructed and then pairwise comparison matrixes are created. Finally, the relative weights are calculated. In conventional AHP, the pairwise comparison is made using crisp scale values. A nine-point scale is a frequently used scale (ranging from 1 for equally important to 9 for extremely preferred). Although the application of crisp values is simple and straightforward, it does not consider uncertainties and vagueness in expert judgments. To overcome this scarcity, fuzzy numbers $(\tilde{a})$ are used in order to capture ambiguous. In this study, a triangular fuzzy number (TFN) is used. A character " $\sim$ " represents a fuzzy set and the TFN is expressed with $\tilde{a}=(a, b, c)$. The parameters $\mathrm{a}, \mathrm{b}$ and $\mathrm{c}$ indicate the smallest possible, most promising and largest possible values, respectively (Alavi 2014; Kumar and Krishna 2018).

The steps of AHP under a fuzzy environment are given as below (Rahimdel and Bagherpour 2018):

\subsubsection{Constructing the Fuzzy Judgment Matrix}

In the first step of the fuzzy AHP, a fuzzy decision matrix with TFNs $\left(\tilde{A}=(\tilde{a})_{n \times n}\right)$ is constructed as Equation 1:

$$
\tilde{A}=\left[\begin{array}{cccc}
1 & \tilde{a}_{12} & \ldots & \tilde{a}_{1 n} \\
\tilde{a}_{21} & 1 & \ldots & \tilde{a}_{2 n} \\
\vdots & \vdots & 1 & \vdots \\
\tilde{a}_{n 1} & \tilde{a}_{n 2} & \ldots & 1
\end{array}\right]
$$

This matrix contains fuzzy numbers $\tilde{a}_{j i}=1 / \tilde{a}_{i j}$. The fuzzy linguistic variables include just equal to extremely preferred and the fuzzy numbers corresponding to them are given in Table 1.

Table 1: Linguistic variables and their corresponding TFN

\begin{tabular}{|l|c|}
\hline Linguistic scale for importance & TFN \\
\hline Just equal & $(1,1,1)$ \\
\hline Equal importance & $(1,1,3)$ \\
\hline Weak importance of one over another & $(1,3,5)$ \\
\hline Moderately importance & $(3,5,7)$ \\
\hline Essential or strong importance & $(5,7,9)$ \\
\hline Very strong importance & $(7,9,10)$ \\
\hline Extremely preferred & $(9,10,10)$ \\
\hline
\end{tabular}

\subsubsection{Calculating the fuzzy synthetic extent value}

After forming the fuzzy decision-making matrix, the synthetic extent value $\left(S_{i}\right)$, a triangle fuzzy number, is calculated for the $i^{\text {th }}$ criterion as shown in Equations 2 and 3:

$$
\begin{gathered}
S_{i}=\sum_{J=1}^{m} M_{g i}^{j}\left[\sum_{i=1}^{n} \sum_{j=1}^{m} M_{g i}^{j}\right]^{-1} \\
\sum_{j=1}^{m} M_{g i}^{j}=\left[\sum_{j=1}^{m} l_{j}, \sum_{j=1}^{m} m_{j}, \sum_{j=1}^{m} u_{j}\right],\left[\sum_{i=1}^{n} \sum_{j=1}^{m} M_{g i}^{j}\right]^{-1}= \\
=\left(\frac{1}{\sum_{j=1}^{m} u_{j}}, \frac{1}{\sum_{j=1}^{m} m_{j}}, \frac{1}{\sum_{j=1}^{m} l_{j}}\right)
\end{gathered}
$$

Where:

Symbol $g$ - the row number

Symbols $i$ and $j$ - the alternatives and criteria

\subsubsection{Calculating the degree of possibility}

In this step, the degree of possibility for each criterion is calculated. The possibility degree of two TFNs, $M_{1}=\left(l_{1}, m_{1}, u_{1}\right) \geq M_{2}=\left(l_{2}, m_{2}, u_{2}\right)$, is defined as Equation 4:

$$
V\left(M_{2} \geq M_{1}\right)= \begin{cases}1, & \text { if } m_{2}>m_{1} \\ 0, & \text { if } l_{1}<u_{2} \\ \frac{l_{1}-u_{2}}{\left(m_{2}-u_{2}\right)-\left(m_{1}-l_{1}\right)}, & \text { otherwise }\end{cases}
$$

Where:

$d$ - the highest intersection point of $\mu_{M 1}$ and $\mu_{M 2}$ as shown in Figure 1.

To compare $M_{1}$ and $M_{2}$, both values $V\left(M_{1} \geq M_{2}\right)$ and $V\left(M_{2} \geq M_{1}\right)$ are required.

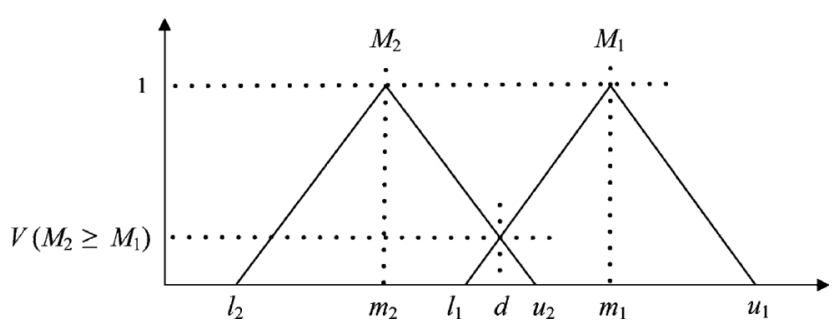

Figure 1: Intersection point $d$ between two fuzzy number $M_{1}$ and $M_{2}$

\subsubsection{Calculating the weight vectors}

With $d^{\prime}\left(A_{i}\right)=\min V\left(S_{i} \geq S_{k}\right)$ for $k=1,2, \ldots, n ; k \neq i$ in consideration, the non-normalized weight vector $\left(W^{\prime}\right)$ is calculated as Equation 5:

$$
W^{\prime}=\left(d^{\prime}\left(A_{1}\right), d^{\prime}\left(A_{2}\right), \ldots, d^{\prime}\left(A_{n}\right)\right)^{T}
$$

Where:

$$
A_{i}(i=1,2, \ldots, n)-n \text { elements. }
$$


The normalized weight vector $(W)$ is calculated as Equation 6:

$$
W=\left(d\left(A_{1}\right), d\left(A_{2}\right), \ldots, d\left(A_{n}\right)\right)^{T}
$$

\subsection{TOPSIS method}

TOPSIS is another MADM method offered by Hwang and Yoon (1981). In this technique, alternatives are ranked based on the distance from an ideal solution and negative ideal solution. On the other hand, the alternative with the shortest distance from the positive ideal solution (the best one) and the biggest distance from the negative ideal solution (the worst case) is ranked in a higher order. This method is understandable and straightforward, and it is used to handle both qualitative and quantitative data sets. The TOPSIS method has been applied to different mining-related decision problems (Wu et. al 2007; Li et al. 2011; Alavi and Alinejad-Rokny 2011; Rahimdel and Karamoozian 2014; Yavuz 2016; Rahimdel and Mirzaei 2020]. Steps of the TOPSIS method are represented below (Rahimdel and Mirzaei 2020):

\subsubsection{Calculating the weighted normalized decision matrix}

In this step, the decision matrix $(A)$ for $n$ alternative and $m$ criterion is formed as Equation 7:

$$
A=\left[\begin{array}{ccc}
x_{11} & \ldots & x_{1 j} \\
\vdots & \ddots & \ldots \\
x_{i 1} & \ldots & x_{i j}
\end{array}\right], j=1, \ldots, n, j=1, \ldots, m
$$

The normalized decision matrix $(R)$ is created as Equation 8:

$$
R=\left[r_{i j}\right]_{m \times n}=\left[\begin{array}{ccc}
r_{11} & \ldots & r_{1 n} \\
\vdots & \ddots & \ldots \\
r_{m 1} & \ldots & r_{m n}
\end{array}\right], j=1, \ldots, n, j=1, \ldots, m(8)
$$

Where:

$r_{i j}$ - the normalized value, calculated as Equation 9:

$$
r_{i j}=\frac{x_{i j}}{\sqrt{\sum_{i=1}^{m} x^{2}{ }_{i j}}}
$$

The weighted normalized decision matrix, with $v_{i j}$ as weighted normalized values, is calculated as Equation 10:

$$
\begin{gathered}
V=\left[v_{i j}\right]_{m \times n}=\left[\begin{array}{ccc}
w_{1} \cdot r_{11} & \ldots & w_{n} \cdot r_{1 n} \\
\vdots & \ddots & \ldots \\
w_{1} \cdot r_{m 1} & \ldots & w_{n} \cdot r_{m n}
\end{array}\right], \\
i=1,2, \ldots, m \cdot j=1,2, \ldots, n
\end{gathered}
$$

Where:

$W_{j}$ - the weight of $j$ criterion that are calculated from the fuzzy AHP method.
2.2.2. Determine the positive-ideal and negative-ideal solution

Positive ideal solution $\left(A^{*}\right)$ and negative ideal solution $\left(A^{-}\right)$for benefit $(I)$ and cost $(J)$ criteria are respectively calculated from the following Equation 11.

$$
\begin{aligned}
& A^{*}=\left\{v_{1}^{*}, v_{2}^{*}, \ldots, v_{n}^{*}\right\}=\left\{\left(\min _{j} v_{i j} \mid i \in I\right)\right\}, \\
& A^{-}=\left\{v_{1}^{-}, v_{2}^{-}, \ldots, v_{n}^{-}\right\}=\left\{\left(\max _{j} v_{i j} \mid i \in J\right)\right\}
\end{aligned}
$$

\subsubsection{Calculating the separation measures and ranking the preference order}

To calculate the separation measures, the $n$-dimensional Euclidean distance is used. In this way, the separation of each alternative from the positive-ideal solution $\left(S_{i}^{*}\right)$ and negative-ideal solution $\left(S_{i}^{-}\right)$are calculated as Equation 12:

$$
S_{j}^{*}=\sqrt{\sum_{i=1}^{n}\left(V_{i j}-V_{i}^{*}\right)^{2}}, \quad S_{j}^{-}=\sqrt{\sum_{i=1}^{n}\left(V_{i j}-V_{j}^{-}\right)^{2}},
$$

For ranking the alternatives, relative closeness $\left(C_{j}^{*}\right)$ to the ideal solution is used as Equation 13:

$$
C_{j}^{*}=\frac{S_{j}^{-}}{S_{j}^{*}+S_{j}^{-}}
$$

The order of all alternatives is determined by considering the descending order of $C_{j}^{*}$ such that the higher $C_{j}^{*}$, the better is the alternative.

\subsection{PROMETHEE method}

PROMETHEE (Preference Ranking Organization Method for Enrichment Evaluation) is a new MADM method proposed by Brans (1982) and then developed by Brans and Vincke (1985). PROMETHEE shows the opposition between all alternatives and considers both qualitative and quantitative attributes with high flexibility and accurate calculations. It also has simpler and more straightforward equations in comparison to other MADM methods. PROMETHEE has been applied in different fields of mining engineering such as the selection of an ore transport system for an underground mine (Elevli and Demirci 2004), the selection of the main mine shaft location (Hudej et al. 2013), management of mine action projects (Mladineo et al. 2016), underground mining method selection (Balusa and Singam 2018; Iphar and Alpay 2019) and safety risk assessment of the mining industry (Gul et al. 2019). This method requires three factors including a decision-making matrix, a degree of importance of the criteria and information related to the preference function, determined by the decision-makers. The preference function is used to define how one object is prioritized in com- 
parison to others. In fact, this function represents an increasing function of deviation. On the other hand, smaller deviations mean weaker preference degrees and larger ones indicate a stronger preference. Six preference functions with specific shapes have been presented in PROMETHEE. The shape of each function is dependent on two thresholds, named $P$ and $Q$. Threshold $Q$ represents the largest deviation, considered negligible while, $P$ (cannot be smaller than $Q$ ) indicates the smallest deviation, considered as decisive (Brans 1982; Brans and Vincke 1985). In PROMETHEE, two parameters, named positive flow $\left(\varphi^{+}\right)$and negative flow $\left(\varphi^{-}\right)$, are calculated for each alternative regarding the given importance degree for each criterion. The character $\varphi^{+}$expresses how much each alternative is higher than all other ones. This means the higher the $\varphi^{+}$, the better the

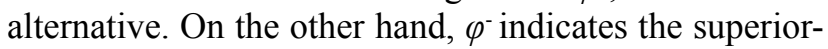
ity of an alternative over the other ones (Behzadian et al. 2010). The steps of the PROMETHEE method are represented below.

\subsubsection{Implementing the preference function and calculating overall preference}

After constructing a decision matrix, the preference function in the creation $j,\left(P_{j}(a, b)\right)$, is applied to decide how much the value $a$ is preferred to $b$ for this criterion. Then, the overall preference index $(\pi(a, b))$, which takes all the criteria into account, is calculated as Equation 14:

Where:

$$
\pi(a, b)=\sum_{j=1}^{k} W_{j} \cdot P_{j}(a, b)
$$

$W_{j}$ - the weight of criteria $j$.

\subsubsection{Calculating positive and negative flows for each alternative}

The positive flow $\left(\varphi^{+}\right)$and negative flow $\left(\varphi^{-}\right)$for each alternative $a \in A$ are respectively, calculated as Equation 15:

$$
\varphi^{+}(a)=\frac{1}{n-1} \sum_{x \in A} \pi(a, x), \quad \varphi^{-}(a)=\frac{1}{n-1} \sum_{x \in A} \pi(x, a)
$$

It is noted that the PROMETHEE I provides a partial ranking of the alternatives while, PROMETHEE II used the net flow $\left(\varphi(a)=\varphi^{+}(a)-\varphi^{-}(a)\right)$ for the ranking of alternatives such that, the alternatives are ranked based on their net flow (Anand and Kodali 2008).

\subsection{Final rank of alternatives}

When there is a difference between the achieved scores for alternatives in applying different MCDM methods, a robust aggregation method needs to be considered. Since, there is no guarantee to obtain the optimum results in averaging the obtained ranks, other methods such as Borda and Copeland rules are applied (Pomerol and Barba-Romero 2012). In the Borda method, a pairwise comparison matrix between the alternatives is constructed regarding their scores obtained from the MCDM methods. This matrix is a zero-one matrix. If the alternative in that row is more rational than the alternative in that column, then the alternative obtains one. Otherwise, it obtains zero. Then, the row sum for each row is calculated for alternative ranking. In the Copeland method, that is a modified version of the Bor$\mathrm{da}$, the number of times that an alternative is preferred over the others is subtracted (row-sum) from the number of times that an alternative is subordinated. A column-

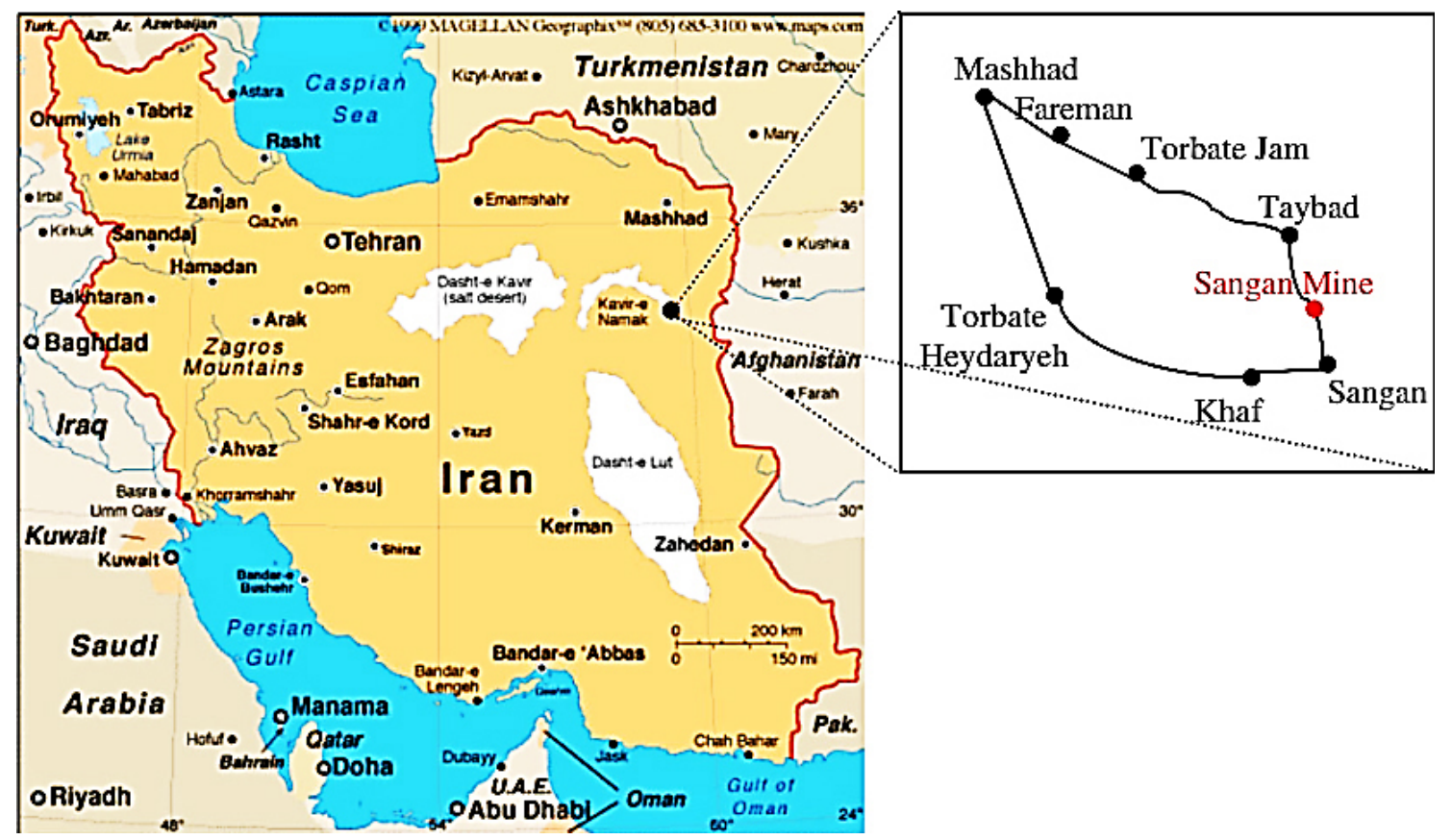

Figure 2: Location of the Sangan Iron Ore Mine 
sum is calculated and used for the alternative ranking (Phelipe et al. 2016).

\section{Case study; Sangan Iron Ore Mine}

The Sangan iron ore mine is located $16 \mathrm{~km}$ north of Sangan city and $300 \mathrm{~km}$ southeast of Mashhad in Razavi Khorasan Province, Iran. The location of this mine is shown in Figure 2. The total geological reserve of this mine was evaluated to be about 1.2 billion tons of iron ore with an average grade of 50 percent $\mathrm{Fe}_{3} \mathrm{O}_{4}$. The annual production of the mine is 4.5 million tons of which 2.6 million tons of iron pellets are produced per year. Drilling equipment is used for blasting holes with different diameters from 76 to $200 \mathrm{~mm}$. In the blasting operation of the mine, vertical blast holes with a diameter of 10,15 , and $20 \mathrm{~cm}$ are drilled in length ranging from 8.5 to $10.5 \mathrm{~m}$. Pattern geometry is staggered and ANFO is the main explosive. The dynamite cartridges are used as a primer and a detonating cord is utilized as the initiation system. The consumed charge per period is $159-964 \mathrm{~kg}$ and the burden to spacing ratio is about 0.65 to 0.87 . More details on these patterns are given in Table 2.

In the first step of the research, the decision-making criteria are defined. In this study, to evaluate DPB, five criteria including specific charge (SC), specific drilling (SD), rock fragmentation (RF), Flyrock (FR) and back break (BB) were considered regarding the past studies and experts' opinions. Specific charge (SC) is the amount of explosives needed to break one ton of rock. This parameter represents the distribution of explosives in the rock mass and has a considerable impact on the blasting results. Specific drilling (SD) is the hole length drilled per one cubic volume of the rock. With an increase in $\mathrm{SD}$, mining costs increase, therefore this parameter has a negative effect on the drilling operation. Rock fragmentation (RF) has a direct effect on the drilling and blasting costs and also on future mining operations such as material transportation and crushing process. RF depends on both rock mass properties (that are uncontrollable) and drilling and blasting design parameters, which can be controlled. An efficient blasting operation can be reached by investigating the relationship between blast design parameters and rock fragmentation. Fly rock (FR) refers to rock pieces that fly beyond the blast site which may cause injuries to people and also damage to equipment, machinery or even structures. This parameter is one of the major issues in blasting operations which must be efficiently controlled. Back break (BB) is defined as the broken rocks beyond the specified limits of the rear row of the drilled holes. This phenomenon is another nega-
Table 2: Geometrical specifications of a drilling pattern considered to select the most proper ones

\begin{tabular}{|l|c|c|c|c|c|}
\hline $\begin{array}{l}\text { Pattern } \\
\text { No. }\end{array}$ & $\begin{array}{c}\text { Hole } \\
\text { diameter } \\
(\mathbf{m m})\end{array}$ & $\begin{array}{c}\text { Stemming } \\
(\mathbf{m})\end{array}$ & $\begin{array}{c}\text { Hole } \\
\text { depth } \\
(\mathbf{m})\end{array}$ & $\begin{array}{c}\text { Spacing } \\
(\mathbf{m})\end{array}$ & $\begin{array}{c}\text { Burden } \\
(\mathbf{m})\end{array}$ \\
\hline P1 & 10 & 2.2 & 8.7 & 3 & 3 \\
\hline P2 & 10 & 2.3 & 8.7 & 3 & 2.5 \\
\hline P3 & 15 & 2.8 & 9.2 & 3 & 2.5 \\
\hline P4 & 20 & 2.7 & 10.5 & 4.5 & 4 \\
\hline P5 & 15 & 2.2 & 9.8 & 3.5 & 3 \\
\hline P6 & 20 & 2.5 & 9.8 & 4.5 & 4 \\
\hline P7 & 15 & 1.9 & 10.2 & 4 & 3.5 \\
\hline P8 & 15 & 1.7 & 8.7 & 3.5 & 3 \\
\hline P9 & 15 & 2.2 & 8.3 & 3.5 & 3 \\
\hline P10 & 20 & 3.4 & 9.6 & 6 & 5 \\
\hline P11 & 15 & 2.2 & 8.5 & 5 & 4 \\
\hline P12 & 15 & 2.1 & 10 & 5 & 4 \\
\hline P13 & 20 & 2.6 & 9.7 & 6 & 6 \\
\hline P14 & 15 & 2.3 & 9.6 & 4 & 3.5 \\
\hline P15 & 15 & 2.7 & 10.3 & 4 & 3.5 \\
\hline P16 & 15 & 2.3 & 10 & 5 & 4 \\
\hline P17 & 15 & 2.5 & 9.3 & 5 & 4 \\
\hline
\end{tabular}

tive issue resulting from a poor blasting operation. $\mathrm{BB}$ causes instability of the mine walls, falling down of machinery and improper fragmentation (Gokhale 2010; Morin and Ficarazzo 2006; Cho and Kaneko 2004). A description of the drilling pattern of the mine, performed previously, is considered as problem attributes.

\section{Results and discussion}

This section is devoted to the selection of the most proper drilling and blasting pattern for the Sangan Iron Ore mine. In the first step, the degree of importance (or weight) of criteria is calculated by using AHP in a fuzzy environment. Then, a decision matrix that includes values of the criteria for the 17 drilling pattern (see Table 2) is created and the TOPSIS and PROMETHEE methods are applied to find the most proper DBP pattern.

\subsection{Calculation of the weight vector}

In the first step of the fuzzy AHP, a decision-making group used linguistic scales (see Table 1) to obtain the TFN comparison matrix. To achieve this, data collected from 14 expert's opinions was applied. Then, the fuzzy comparison matrix for all criteria is created as given in Table 3.

The synthetic extent values $\left(S_{i}\right)$ were calculated for each criterion and then, the possibility degrees of each pairwise criteria were calculated as follows:

Table 3: The pairwise comparison matrix for all criteria

\begin{tabular}{|l|l|l|l|l|l|}
\hline & BB & FR & RF & SC & SD \\
\hline BB & $(1,1,1)$ & $(1,3.17,6)$ & $(0.11,0.69,3.00)$ & $(0.14,0.41,1)$ & $(0.17,1.05,4)$ \\
\hline FR & $(0.17,0.32,1)$ & $(1,1,1)$ & $(0.11,0.50,1)$ & $(0.13,0.30,1)$ & $(0.13,0.26,0.50)$ \\
\hline RF & $(0.33,1.45,9.01)$ & $(1,2.01,9.01)$ & $(1,1,1)$ & $(1,5,9)$ & $(1,4.14,9)$ \\
\hline SC & $(1,2.43,7.04)$ & $(1,3.37,8)$ & $(0.11,0.2,1)$ & $(1,1,1)$ & $(1,1.76,5)$ \\
\hline SD & $(0.25,0.95,6.03)$ & $(2,3.82,8)$ & $(0.11,0.24,1)$ & $(0.10,0.20,0.57)$ & $(1,1,1)$ \\
\hline
\end{tabular}




$\begin{array}{llll}V\left(S_{1}>S_{2}\right)=1, & V\left(S_{1}>S_{3}\right)=0.814, & V\left(S_{1}>S_{4}\right)=0.814, & V\left(S_{1}>S_{5}\right)=1.073, \\ V\left(S_{2}>S_{1}\right)=0.968, & V\left(S_{2}>S_{3}\right)=0.807, & V\left(S_{2}>S_{4}\right)=0.934, & V\left(S_{2}>S_{5}\right)=0.982, \\ V\left(S_{3}>S_{1}\right)=1, & V\left(S_{3}>S_{2}\right)=1, & V\left(S_{3}>S_{4}\right)=1, & V\left(S_{3}>S_{5}\right)=1, \\ V\left(S_{4}>S_{1}\right)=1, & V\left(S_{4}>S_{2}\right)=1, & V\left(S_{4}>S_{3}\right)=0.913, & V\left(S_{4}>S_{5}\right)=1, \\ V\left(S_{5}>S_{1}\right)=1, & V\left(S_{5}>S_{2}\right)=1, & V\left(S_{5}>S_{3}\right)=0.907, & V\left(S_{5}>S_{4}\right)=1.034 .\end{array}$

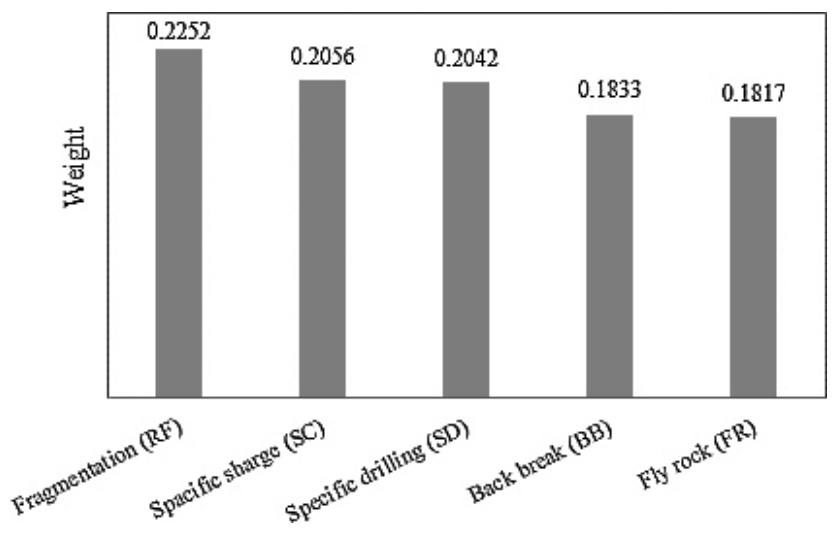

Figure 3: The weight of each decision criteria achieve this, the practical results of the formerly performed pattern were considered as the decision matrix as given in Table 4. It is noted that all criteria except RF and $\mathrm{BB}$ are expressed in the form of numerical values which means they are not measured systematically. Therefore, in the first step, the qualitative criteria (RF and $\mathrm{BB}$ ) were converted to numerical values while considering values 1, 2 and 3 as acceptable, fairly acceptable and unacceptable levels, respectively. Then, a normalized decision matrix was created using Equation (12). The weighted normalized decision matrix was formed using Equation (13) and Table 4 and given in Table 5. The positive ideal solution () and negative-ideal solution () were computed using Table 5 and Equation

Table 4: Decision matrix

\begin{tabular}{|l|l|l|l|l|l|}
\hline DBP No. & BB & SD $\left(\mathbf{m} / \mathbf{m}^{\mathbf{3}}\right)$ & FR $(\mathbf{m})$ & RF & SC $\left(\mathbf{g r} / \mathbf{m}^{\mathbf{3}}\right)$ \\
\hline P1 & Acceptable & 0.111 & 30 & Acceptable & 205 \\
\hline P2 & Fairly-acceptable & 0.157 & 40 & Acceptable & 271 \\
\hline P3 & Fairly-acceptable & 0.133 & 29 & Acceptable & 252 \\
\hline P4 & Unacceptable & 0.070 & 155 & Unacceptable & 336 \\
\hline P5 & Fairly-acceptable & 0.092 & 38 & Fairly-acceptable & 244 \\
\hline P6 & Unacceptable & 0.058 & 103 & Unacceptable & 290 \\
\hline P7 & Unacceptable & 0.071 & 92 & Fairly-acceptable & 307 \\
\hline P8 & Fairly-acceptable & 0.095 & 44 & Fairly-acceptable & 252 \\
\hline P9 & Fairly-acceptable & 0.085 & 21 & Fairly-acceptable & 225 \\
\hline P10 & Unacceptable & 0.036 & 79 & Unacceptable & 269 \\
\hline P11 & Acceptable & 0.051 & 13 & Fairly-acceptable & 215 \\
\hline P12 & Fairly-acceptable & 0.055 & 38 & Fairly-acceptable & 245 \\
\hline P13 & Fairly-acceptable & 0.031 & 34 & Unacceptable & 230 \\
\hline P14 & Fairly-acceptable & 0.037 & 26 & Fairly-acceptable & 231 \\
\hline P15 & Acceptable & 0.122 & 43 & Fairly-acceptable & 205 \\
\hline P16 & Acceptable & 0.047 & 52 & Fairly-acceptable & 206 \\
\hline P17 & Acceptable & 0.054 & 28 & Fairly-acceptable & 221 \\
\hline
\end{tabular}

According to the possibility degree values, the normalized weight of the criteria was calculated and shown in Figure 3. The results indicate that rock fragmentation and fly rock have the highest and lowest importance, respectively.

\subsection{Selection of the most proper DBP using the TOPSIS method}

This subsection tried to select the most proper DBP for the studied mine by using the TOPSIS method. To
(14) and given in Table 6. The distance between each alternative and and was calculated and then the closeness coefficient of the alternatives was calculated to rank a drilling pattern. The results are given in Table 6. Regarding the results, alternatives P16 and P4 are the best and worst patterns, respectively.

\subsection{Selection of the most proper DBP using the PROMETHEE method}

In this subsection, the most suitable drilling pattern is selected using the PROMETHEE method. In this meth- 
Table 5: Weighted normalized matrix

\begin{tabular}{|l|c|c|c|c|c|}
\hline DBP No. & BB & SD & RF & RF & SC \\
\hline P1 & 0.0215 & 0.0649 & 0.0021 & 0.0802 & 0.0414 \\
\hline P2 & 0.0429 & 0.0918 & 0.0302 & 0.0802 & 0.0548 \\
\hline P3 & 0.0429 & 0.0778 & 0.0221 & 0.0802 & 0.0509 \\
\hline P4 & 0.0644 & 0.0409 & 0.1156 & 0.0267 & 0.0594 \\
\hline P5 & 0.0429 & 0.0538 & 0.0281 & 0.0535 & 0.0493 \\
\hline P6 & 0.0644 & 0.0339 & 0.0765 & 0.0267 & 0.0586 \\
\hline P7 & 0.0644 & 0.0415 & 0.0682 & 0.0535 & 0.0620 \\
\hline P8 & 0.0429 & 0.0556 & 0.0332 & 0.0535 & 0.0509 \\
\hline P9 & 0.0429 & 0.0497 & 0.0159 & 0.0535 & 0.0455 \\
\hline P10 & 0.0644 & 0.0211 & 0.0587 & 0.0267 & 0.0543 \\
\hline P11 & 0.0215 & 0.0298 & 0.0096 & 0.0535 & 0.0434 \\
\hline P12 & 0.0429 & 0.0322 & 0.0287 & 0.0535 & 0.0495 \\
\hline P13 & 0.0429 & 0.0181 & 0.0255 & 0.0267 & 0.0465 \\
\hline P14 & 0.0429 & 0.0216 & 0.0198 & 0.0535 & 0.0467 \\
\hline P15 & 0.0215 & 0.0713 & 0.0032 & 0.0535 & 0.0414 \\
\hline P16 & 0.0215 & 0.0275 & 0.0038 & 0.0535 & 0.0416 \\
\hline P17 & 0.0215 & 0.0316 & 0.0134 & 0.0535 & 0.0446 \\
\hline
\end{tabular}

Table 6: Fuzzy positive and negative ideal solutions

\begin{tabular}{|l|c|c|}
\hline & $A^{-}$ & $A^{*}$ \\
\hline SC & 0.0620 & 0.0414 \\
\hline RF & 0.0802 & 0.0267 \\
\hline FR & 0.1156 & 0.0021 \\
\hline SD & 0.0918 & 0.0181 \\
\hline BB & 0.0643 & 0.0214 \\
\hline
\end{tabular}

od, to select the most proper alternative, the comparison matrix for all alternatives is created. Regarding the high volume of calculations and the limitation of page numbers, the details of the calculations have been omitted. The overall preference index $(\pi(a, b))$ is calculated by using Equation (14) and Table 5 and given in Table 8. The positive, negative and net flows are calculated regarding Table 8 and Equation (15). The results are presented in Table 9. Regarding Table 9, pattern No. 16 is selected as the most proper drilling pattern, which is consistent with the TOPSIS results.

The final rank of the pattern in the application of the Copeland aggregation method is given in Table 10. Regarding the results, pattern No. 16 is selected as the most suitable alternative. It is worth noting that the specific charge and specific drilling of this pattern is 38.77 and 16.70 percent lower than the average ones, respectively. The rock fragmentation of the pattern no. 16 equals the average rock fragmentation of all studied patterns and the back break is acceptable.
Table 7: Closeness coefficient of alternatives

\begin{tabular}{|l|c|c|c|}
\hline DBP No. & $S_{i}^{-}$ & $S_{i}^{*}$ & $\boldsymbol{C}_{\boldsymbol{i}}$ \\
\hline P1 & 0.1260 & 0.0710 & 0.6394 \\
\hline P2 & 0.0884 & 0.0985 & 0.4728 \\
\hline P3 & 0.0976 & 0.0858 & 0.5321 \\
\hline P4 & 0.0738 & 0.1247 & 0.3718 \\
\hline P5 & 0.1022 & 0.0564 & 0.6444 \\
\hline P6 & 0.0880 & 0.0890 & 0.4973 \\
\hline P7 & 0.0741 & 0.0889 & 0.4547 \\
\hline P8 & 0.0970 & 0.0602 & 0.6169 \\
\hline P9 & 0.1147 & 0.0488 & 0.7016 \\
\hline P10 & 0.1057 & 0.0722 & 0.5941 \\
\hline P11 & 0.1341 & 0.0302 & 0.8163 \\
\hline P12 & 0.1115 & 0.0463 & 0.7067 \\
\hline P13 & 0.1308 & 0.0321 & 0.8028 \\
\hline P14 & 0.1246 & 0.0391 & 0.7613 \\
\hline P15 & 0.1266 & 0.0596 & 0.6801 \\
\hline P16 & $\mathbf{0 . 1 4 0 0}$ & $\mathbf{0 . 0 2 8 4}$ & $\mathbf{0 . 8 3 1 5}$ \\
\hline P17 & 0.1301 & 0.0321 & 0.8020 \\
\hline
\end{tabular}

\section{Conclusion}

Drilling and blasting is the most common method applied in open pit mining which is a very important part of a mining operation. Improper drilling and blasting operations may lead to adverse technical and safety consequences such as fly rock, back break and therefore, increases in the operating costs of mines. In this paper, the most ideal drilling and blasting pattern was proposed for the Sangan Iron Mine, Iran. Specific charge, fly rock, rock fragmentation, back break and specific drilling were considered as decision criteria and the most suitable drilling pattern was selected among 17 patterns, all previously performed. The AHP method under a fuzzy environment was used to define the weight of criteria and the TOPSIS and PROMETHEE methods were applied to select the most ideal drilling and blasting pattern. Regarding the results of this study, rock fragmentation, specific charge and specific drilling have the highest degree of importance, respectively. A drilling and blasting pattern with a spacing of $5 \mathrm{~m}$, a burden of $4 \mathrm{~m}$, a hole depth of $10 \mathrm{~m}$, and a hole diameter of $15 \mathrm{~cm}$ is proposed as the most proper alternative. Considering the effect of the suggested pattern on direct and indirect costs of the mining operation, studying the effect of the proposed pattern on ground vibration and air blast and applying other multi-attribute decision-making methods to find the most suitable alternative could be recommended for future studies. 
Table 8: Matrix of preference function for drilling patterns

\begin{tabular}{|c|c|c|c|c|c|c|c|c|c|}
\hline DBP No. & 1 & 2 & 3 & 4 & 5 & 6 & 7 & 8 & 9 \\
\hline $\mathrm{P} 1$ & 0 & 0.583 & 0.583 & 0.618 & 0.618 & 0.618 & 0.618 & 0.618 & 0.618 \\
\hline $\mathrm{P} 2$ & 0.187 & 0 & 0 & 0.805 & 0.230 & 0.805 & 0.805 & 0.408 & 0.230 \\
\hline $\mathrm{P} 3$ & 0.187 & 0.583 & 0 & 0.805 & 0.408 & 0.805 & 0.805 & 0.408 & 0.230 \\
\hline $\mathrm{P} 4$ & 0.382 & 0.195 & 0.195 & 0 & 0.195 & 0 & 0.195 & 0.195 & 0.195 \\
\hline $\mathrm{P} 5$ & 0.382 & 0.583 & 0.405 & 0.805 & 0 & 0.805 & 0.575 & 0.583 & 0 \\
\hline P6 & 0.382 & 0.195 & 0.195 & 0.583 & 0.195 & 0 & 0.405 & 0.195 & 0.195 \\
\hline $\mathrm{P} 7$ & 0.382 & 0.195 & 0.195 & 0.618 & 0.195 & 0.408 & 0 & 0.195 & 0.195 \\
\hline P8 & 0.382 & 0.405 & 0.195 & 0.805 & 0 & 0.805 & 0.575 & 0 & 0 \\
\hline P9 & 0.382 & 0.583 & 0.583 & 0.805 & 0.583 & 0.805 & 0.575 & 0.583 & 0 \\
\hline $\mathrm{P} 10$ & 0.382 & 0.405 & 0.195 & 0.583 & 0.195 & 0.583 & 0.583 & 0.195 & 0.195 \\
\hline P11 & 0.195 & 0.770 & 0.592 & 1 & 0.770 & 1 & 0.770 & 0.770 & 0.770 \\
\hline $\mathrm{P} 12$ & 0.382 & 0.583 & 0.405 & 1 & 0.195 & 1 & 0.770 & 0.583 & 0.195 \\
\hline P13 & 0.382 & 0.583 & 0.405 & 0.770 & 0.583 & 0.770 & 0.770 & 0.583 & 0.195 \\
\hline P14 & 0.382 & 0.583 & 0.583 & 1 & 0.583 & 1 & 0.770 & 0.583 & 0.195 \\
\hline P15 & 0 & 0.770 & 0.770 & 0.805 & 0.575 & 0.805 & 0.575 & 0.575 & 0.195 \\
\hline $\mathrm{P} 16$ & 0.195 & 0.575 & 0.770 & 1 & 0.770 & 1 & 0.770 & 0.770 & 0.770 \\
\hline P17 & 0.195 & 0.770 & 0.770 & 1 & 0.770 & 1 & 0.770 & 0.770 & 0.770 \\
\hline DBP No. & 10 & 11 & 12 & 13 & 14 & 15 & 16 & 17 & \\
\hline $\mathrm{P} 1$ & 0.618 & 0.618 & 0.618 & 0.618 & 0.618 & 0.618 & 0.618 & 0.618 & \\
\hline $\mathrm{P} 2$ & 0.595 & 0.230 & 0.230 & 0.230 & 0.230 & 0.230 & 0.425 & 0.230 & \\
\hline P3 & 0.805 & 0.408 & 0.408 & 0.408 & 0.230 & 0.230 & 0.230 & 0.230 & \\
\hline P4 & 0 & 0 & 0 & 0 & 0 & 0.195 & 0 & 0 & \\
\hline $\mathrm{P} 5$ & 0.805 & 0 & 0.388 & 0.230 & 0 & 0.195 & 0 & 0 & \\
\hline P6 & 0 & 0 & 0 & 0 & 0 & 0.195 & 0 & 0 & \\
\hline P7 & 0.230 & 0 & 0 & 0.230 & 0 & 0.195 & 0 & 0 & \\
\hline P8 & 0.805 & 0 & 0 & 0.230 & 0 & 0.195 & 0 & 0 & \\
\hline P9 & 0.805 & 0 & 0.388 & 0.618 & 0.388 & 0.195 & 0 & 0 & \\
\hline P10 & 0 & 0.195 & 0.195 & 0 & 0.195 & 0.195 & 0.195 & 0.195 & \\
\hline P11 & 0.805 & 0 & 0.770 & 0.805 & 0.575 & 0.195 & 0 & 0.583 & \\
\hline P12 & 0.805 & 0 & 0 & 0.230 & 0 & 0.195 & 0 & 0 & \\
\hline P13 & 0.770 & 0.195 & 0.583 & 0 & 0.405 & 0.195 & 0.195 & 0.195 & \\
\hline P14 & 0.805 & 0.195 & 0.583 & 0.408 & 0 & 0.195 & 0.195 & 0.195 & \\
\hline $\mathrm{P} 15$ & 0.805 & 0.388 & 0.575 & 0.805 & 0.575 & 0 & 0.388 & 0.388 & \\
\hline P16 & 0.805 & 0.583 & 0.770 & 0.805 & 0.575 & 0.195 & 0 & 0.583 & \\
\hline P17 & 0.805 & 0 & 0.770 & 0.805 & 0.575 & 0.195 & 0 & 0 & \\
\hline
\end{tabular}

Table 9: The positive, negative and net flows for all alternatives

\begin{tabular}{|l|l|l|l|l|l|l|l|}
\hline DBP No. & $\boldsymbol{\varphi}^{+}$ & $\boldsymbol{\varphi}^{-}$ & $\boldsymbol{\varphi}$ & DBP No. & $\boldsymbol{\varphi}^{+}$ & $\boldsymbol{\varphi}^{-}$ & \multicolumn{1}{l|}{} \\
\hline P1 & 0.6217 & 0.2867 & 0.3351 & P10 & 0.2924 & 0.6277 & -0.3353 \\
\hline P2 & 0.3708 & 0.5077 & -0.1369 & P11 & 0.6617 & 0.1690 & 0.4927 \\
\hline P3 & 0.4544 & 0.4124 & 0.0420 & P12 & 0.4060 & 0.3714 & 0.0346 \\
\hline P4 & 0.1079 & 0.8122 & -0.7043 & P13 & 0.4863 & 0.3922 & 0.0941 \\
\hline P5 & 0.3742 & 0.4148 & -0.0406 & P14 & 0.5239 & 0.2652 & 0.2587 \\
\hline P6 & 0.1641 & 0.7457 & -0.5816 & P15 & 0.5955 & 0.2235 & 0.3720 \\
\hline P7 & 0.1744 & 0.6516 & -0.4772 & P16 & $\mathbf{0 . 6 9 3 1}$ & $\mathbf{0 . 1 3 7 6}$ & $\mathbf{0 . 5 5 5 5}$ \\
\hline P8 & 0.2871 & 0.4904 & -3.660 & P17 & 0.6392 & 0.1915 & 0.4477 \\
\hline P9 & 0.4695 & 0.3196 & -0.2033 & & & & \\
\hline
\end{tabular}


Table 1o: Final ranking of the drilling and blasting pattern based on the Copeland method

\begin{tabular}{|l|c|c|c|c|c|}
\hline DBP No. & Value & Rank & DBP No. & Value & Rank \\
\hline P1 & 4 & 7 & P10 & -6 & 12 \\
\hline P2 & -7 & 13 & P11 & 14 & 2 \\
\hline P3 & -2 & 11 & P12 & 4 & 8 \\
\hline P4 & -14 & 17 & P13 & 10 & 4 \\
\hline P5 & 0 & 9 & P14 & 8 & 5 \\
\hline P6 & -10 & 15 & P15 & 7 & 6 \\
\hline P7 & -11 & 16 & P16 & $\mathbf{1 6}$ & $\mathbf{1}$ \\
\hline P8 & -9 & 14 & P17 & 12 & 8 \\
\hline P9 & 0 & 10 & & & \\
\hline
\end{tabular}

\section{References}

Alavi, I., (2014): Fuzzy AHP method for plant species selection in mine reclamation plans: case study sungun copper mine. Iranian Journal of Fuzzy Systems, 11, 5, 23-38.

Alavi, I., Alinejad-Rokny, H. (2011): Comparison of Fuzzy AHP and Fuzzy TOPSIS methods for plant species selection (case study: reclamation plan of sungun Copper Mine; Iran). Australian Journal of Basic and Applied Sciences, 5, $12,1104-1113$.

Anand, G., Kodali, R. (2008): Selection of lean manufacturing systems using the PROMETHEE. Journal of Modelling in Management, 3, 1, 40-70.

Bajpayee, T., Bhatt, SK., Rehak, TR., Engineer, G., Mowrey, G.L., Ingram, D.K. (2003): Fatal accidents due to flyrock and lack of blast area security and working practices in mining. Journal of mines, metals and fuels, 51, 344-349.

Bajpayee, T., Rehak, T., Mowrey, G., Ingram, D. (2004): Blasting injuries in surface mining with emphasis on flyrock and blast area security. Journal of Safety Research, 35, 47-57.

Bakhshandeh Amnieh, H., Siamaki, A., Soltani, S. (2012): Design of blasting pattern in proportion to the peak particle velocity (PPV): Artificial neural networks approach. Safety Science, 50, 9, 1913- 1916.

Balusa, B.C., Singam, J. (2018): Underground mining method selection using WPM and PROMETHEE. Journal of the Institution of Engineers (India): Series D, 99, 1,165-171.

Behzadian, M., Kazemzadeh, R.B., Albadvi A, Aghdasi M (2010): PROMETHEE: A comprehensive literature review on methodologies and applications. European Journal of Operational Research. 200: 198-215.

Brans, J.P. (1982): Lingenierie de la decision. Elaboration dinstruments daide a la decision. Methode PROMETHEE. In: Nadeau, R., Landry, M. (Eds.), Laide a la Decision: Nature, Instrument set Perspectives Davenir. Presses de Universite Laval, Quebec, Canada, 183-214.

Brans, J., Vincke, P. (1985): A preference ranking organization method (The PROMETHEE method for multiple

criteria decision making). Manage Sci. 31, 6, 647-656

Cho, S.H., Kaneko, K. (2004): Rock fragmentation control in blasting. Materials Transactions, 45, 5, 1722-1730.
Despodov Z, Mitić S. Peltečki, D (2011): Application of the AHP method for selection of a transportation system in mine planning. Podzemni radovi, 19, 93-99.

Elevli, B., Demirci, A. (2004): Multicriteria choice of ore transport system for an underground mine: application of PTOMETHEE methods. Journal of the Southern African Institute of Mining and Metallurgy, 104, 5, 251-256.

Gate, W., Ortiz, B., Florez, R. (2005): Analysis of rockfall and blasting backbreak problems. In: American Rock Mechanics Association (ARMA) Staff (eds.): 40 ${ }^{\text {th }}$ American rock mechanics conference. - Curran Associates Publ. Co. 5, 671-680, $1690 \mathrm{p}$.

Ghasemi, E., Amnieh, H.B. and Bagherpour, R. (2016): Assessment of backbreak due to blasting operation in open pit mines: a case study. Environmental Earth Sciences, 75, 7, 552.

Gokhale, B.V. (2010): Rotary drilling and blasting in large surface mines. CRC Press, Taylor \& Francis Group, London, $748 \mathrm{p}$.

Gul, M., Ak, M.F., Guneri, A.F. (2019): Pythagorean fuzzy VIKOR-based approach for safety risk assessment in mine industry. Journal of Safety Research, 69, 135-153.

Guosheng, Z., Jiang, L., Kui, Z. (2011): Structural safety criteria for blasting vibration based on wavelet packet energy spectra. Mining Science and Technology (China), 21, 1, 35-40.

Gupta, S., Kumar, U. (2012): An analytical hierarchy process (AHP)-guided decision model for underground mining method selection. International Journal of Mining, Reclamation and Environment, 26, 4, 324-336.

Hudaverdi, T. (2012): Application of multivariate analysis for prediction of blast-induced ground vibrations. Soil Dynamics and Earthquake Engineering, 43, 300-308.

Hudej, M., Vujic, S., Radosavlevic, M., and Ilic, S. (2013): Multi-variable selection of the main mine shaft location. Journal of Mining Science, 49, 6, 950-954.

Hwang, C.L., Yoon, K. (1981): Multiple attribute decision making: Methods and applications. - Springer Verlag Berlin Heidelberg, New York, 269 p.

Iphar, M., Alpay, S. (2019): A mobile application based on multi-criteria decision-making methods for underground mining method selection. International Journal of Mining, Reclamation and Environment, 33, 7, 480-504.

Khandelwal, M., Monjezi, M. (2012): Prediction of backbreak in open-pit blasting operations using the machine learning method. Rock Mechanics and Rock Engineering, 46, 2, 389-396.

Kumar, A., Krishna, A.P. (2018): Assessment of groundwater potential zones in coal mining impacted hard-rock terrain of India by integrating geospatial and analytic hierarchy process (AHP) approach. Geocarto International, 33, 2, 105-129.

Li, X., Wang, K., Liu, L., Xin, J., Yang, H., Gao, C. (2011): Application of the entropy weight and TOPSIS method in safety evaluation of coal mines. Procedia Engineering, 26, 2085-2091.

Little, T., Blair, D. (2010): Mechanistic Monte Carlo models for analysis of flyrock risk. In: Sanchidrián, J.A. (ed.): $9^{\text {th }}$ 
International Symposium of Rock fragmentation by blasting, - CRC Press, Taylor \& Francis Ltd., 641-647, 872 p.

Mladineo, M., Jajac, N., Rogulj, K. (2016): A simplified approach to the PROMETHEE method for priority setting in management of mine action projects. Croatian Operational Research Review, 7, 2, 249-268.

Monjezi, M., Amini Khoshalan, H., Yazdian Varjani, A. (2012a): Prediction of flyrock and backbreak in open pit blasting operation: a neuro-genetic approach. Arabian Journal of Geosciences, 5, 3, 441-448.

Monjezi, M., Dehghan, H. and Samimi Namin, F. (2007): Application of TOPSIS method in controlling fly rock in blasting operations. In: $7^{\text {th }}$ International Scientific Conference of Modern Management of Mine Producing, Geology and Environmental Protection (SGEM 2007), - Curran Associates Publ., 41-49, 1024 p.

Monjezi, M., Dehghani, H., Singh, T.N., Sayadi, A.R., Gholinejad, A. (2012): Application of TOPSIS method for selecting the most appropriate blast design. Arabian journal of geosciences, 5, 1, 95-101.

Morin, M.A., Ficarazzo, F. (2006): Monte Carlo simulation as a tool to predict blasting fragmentation based on the KuzRam model. Computers and Geosciences, 32, 3, 352-359.

Ooriad, F.A., Yari, M., Bagherpour, R. and Khoshouei, M. (2018): The development of a novel model for mining method selection in a fuzzy environment; case study: Tazareh Coal Mine, Semnan Province, Iran. The Mining, Geological, Petroleum Engineering Bulletin (Rudarskogeološko-naftni zbornik), 33, 1, 45-53.

Pohekar, S.D., Ramachandran, M. (2004): Application of multi-criteria decision making to sustainable energy planning - a review. Renewable and Sustainable Energy Reviews, 8, 365-381.

Rahimdel, M.J., Ataei, M. (2014): Application of analytical hierarchy process to selection of primary crusher. International Journal of Mining Science and Technology, 24, 4, 519-523.

Rahimdel, M.J., Bagherpour, R. (2018): Haulage system selection for open pit mines using fuzzy MCDM and the view on energy saving. Neural Computing and Applications, 291, 6, 187-199.

Rahimdel, M.J., Karamoozian, M. (2014): Fuzzy TOPSIS method to primary crusher selection for Golegohar Iron Mine (Iran). Journal of Central South University, 21, 11, 4352-4359.

Rahimdel, M.J., Mirzaei, M. (2020): Prioritization of practical solutions for the vibrational health risk reduction of mining trucks using fuzzy decision making. Archives of Environmental \& Occupational Health, 75, 2, 112-126.
Rahimdel, M.J., Noferesti, H. (2020): Investment preferences of Iran's mineral extraction sector with a focus on the productivity of the energy consumption, water and labor force. Resources Policy, 67, https://doi.org/10.1016/j.resourpol.2020.101695.

Samanta, B., Sarkar, B., Mukherjee, S.K. (2002): Selection of opencast mining equipment by a multi-criteria decisionmaking process. Mining Technology, 111, 2, 136-142.

Shi, X.Z., Zhou, J., Wu, B.B., Huang, D., Wei, W.E.I. (2012): Support vector machines approach to mean particle size of rock fragmentation due to bench blasting prediction. Trans Nonferrous Met Soc China, 22, 2, 432-441.

Stojadinović, S., Pantović, R., Žikić, M. (2011): Prediction of flyrock trajectories for forensic applications using ballistic flight equations. International Journal of Rock Mechanics and Mining Sciences, 48, 7, 1086-1094.

Wu, L.Y., Yang, Y.Z., Zhang, Q. (2007): TOPSIS method for evaluation on mine ventilation system. Journal of China Coal Society, 32, 407-410.

Yari, M., Bagherpour, R., Jamali, S. (2017): Development of an evaluation system for blasting patterns to provide efficient production. Journal of Intelligent Manufacturing, 28, 4, 975-984.

Yari, M., Monjezi, M., Bagherpour, R. (2013): Selecting the most suitable blasting pattern using AHP-TOPSIS method: Sungun copper mine. Journal of Mining Science, 49, 6, 967-975.

Yari, M., Bagherpour, R., Jamali, S. and Asadi, F. (2015): Selection of most proper blasting pattern in mines using linear assignment method: Sungun copper mine. Archives of Mining Sciences, 60, 1, 375-386.

Yari, M., Monjezi, M. Bagherpour, R. (2014a): A novel investigation in blasting operation management using decision making methods. The Mining, Geological, Petroleum Engineering Bulletin (Rudarsko-geološko-naftni zbornik), 29, 1, 69.

Yari, M., Monjezi, M., Bagherpour, R. Jamali, S. (2014b): Developing a mathematical assessment model for blasting patterns management: Sungun copper mine. Journal of Central South University, 21, 11, 4344-4351.

Yari M., Monjezi M., Bagherpour R., Sayadi A.R. (2015): Blasting Operation Management Using Mathematical Methods. In: Lollino, G. Manconi, A. Clague, J. Shan, W. Chiarle, M. (eds.): Engineering Geology for Society and Territory. - Springer Publ. Co., 483-493, 572 p.

Yavuz, M. (2016): Equipment selection by using fuzzy TOPSIS method. In: Yilmaz, I. (ed.): World Multidisciplinary Earth Sciences Symposium (WMESS 2016). - Curran Associates, Inc., 646-650, 1074 p. 


\section{SAŽETAK}

\section{Odabir najprikladnijega načina bušenja i miniranja upotrebom MADM metoda (studija slučaja: Rudnik željeza Sangan, Iran)}

Bušenje je prva faza površinske eksploatacije koja ima znatan utjecaj na ostale faze rudarenja, uključujući miniranje, utovar, transport i drobljenje. Neprimjeren način bušenja može dovesti do nepoželjnih rezultata poput loše fragmentacije, povratnoga loma i odbacivanja stijena, što ne samo da rezultira tehničkim i sigurnosnim problemima, već i povećava operativne troškove rudnika. Metode donošenja odluka s više atributa (MADM) mogu biti korisne za odabir odgovarajućega načina bušenja među raznim prethodno izvedenim alternativama. Cilj je ovoga rada odabrati najpogodniji način bušenja i miniranja za rudnik željeza Sangan, Iran. Da bi se to postiglo, u prvome koraku kao kriteriji za odlučivanje razmatrani su fragmentacija stijena, povratno lomljenje, odbacivanje stijena, specifično punjenje i specifično bušenje, a njihova važnost izračunana je korištenjem AHP metode u neizrazitome okruženju. Zatim su korištene metode TOPSIS i PROMETHEE za odabir najprikladnije alternative. Rezultati ove studije pokazuju da je najprikladniji način bušenja s razmakom od $5 \mathrm{~m}$, opterećenjem od $4 \mathrm{~m}$, dubinom rupe od $10 \mathrm{~m}$ i promjerom rupe od $15 \mathrm{~cm}$. Duljina čepa bušotine i specifična potrošnja eksploziva predloženoga uzorka iznose $2,3 \mathrm{~m}$, odnosno $2,6 \mathrm{~g} / \mathrm{cm}^{3}$.

\section{Ključne riječi:}

način bušenja i miniranja, rudnik željeza Sangan, AHP, TOPSIS, PROMETHEE

\section{Authors contribution}

A. Aryafar and M.J. Rahimdel (Associate and Assistant Professor of Mining Engineering) contributed to the design and implementation of the research. E. Tavakkoli (M.Sc. of Mining Engineering) performed the field work. 